\title{
THE POWER OF LANGUAGE: PRESENTATIONAL STYLE IN THE COURTROOM*
}

\author{
JOHN M. CONLEY,** \\ WILLIAM M. O'BARR*** \\ AND E. ALLAN LIND****
}

\section{INTRODUCTION}

Legal writers have long speculated about various aspects of human behavior. In the area of trial tactics, such speculation has focused on the probable effects of various trial events upon the thoughts and actions of judges, juries, witnesses and attorneys. Traditionally, writers concerned with tactical issues have offered suggestions based on their own experiences in trials and on their intuitions about human nature. ${ }^{1}$ This Article, however, takes a new approach by bringing the observational, analytical and experimental methods of social science to bear on a question affecting trial tactics: the effect of variations in the presentational style of courtroom witnesses upon legal decision makers. ${ }^{2}$

The rules of evidence control the content of testimony that may be

* The research reported here was supported by a National Science Foundation Law and Social Science Program Grant (GS-42742). The authors gratefully acknowledge the invaluable assistance provided by Laurens Walker, Bruce Johnson, Lawrence Rosen, Kim Atkins, Marilyn Endriss, Debbie Mercer, Michael Porter, Bill Schmidheiser and Liane Bidwell. The cooperation of Superior Court of Durham County, N.C. and of the many practicing attorneys who took time from busy workdays to talk with us is also gratefully acknowledged.

** Associate, Fleming, Robinson, Bradshaw \& Hinson, Charlotte, N.C. B.A. 1971, Harvard College; J.D. 1977, Duke University School of Law; Ph.D. candidate in Anthropology, Duke University.

*** Associate Professor of Anthropology; Director, Law and Language Program, Duke University. B.A. 1964, Emory University; M.A. 1966, Ph.D. 1969, Northwestern University.

**** Research Social Psychologist, Federal Judicial Center, Washington, D.C. B.A. 1970, University of Florida; M.A. 1973, Ph.D. 1974, University of North Carolina.

1. See, e.g., F. Bailey \& H. Rothblatt, Successful Techniques for Criminal Trials (1971); J. Jeans, Trial Advocacy (1975); R. Keeton, Triai Tactics and Methods (2d ed. 1973); J. McElhaney, Effective Litigation-Trials, Problems, and Materials (1974); A. Morrill, Trial Diplomacy (1971).

2. "Presentational style" is a comprehensive term including both verbal and nonverbal behavior. The latter includes what is commonly termed "demeanor" or "presence." See note 3 infra. That presentational styles can and do have an impact on jurors is often the underlying assumption in other studies dealing with trial tactics and courtroom presentation. See, e.g., G. Miller \& N. Fontes, Real Versus Reel: What's the Verdict 73 (1979). 
introduced at trial. Those same rules, however, place relatively few constraints on how testimony is presented once it is deemed admissible. This freedom in testimonial style, together with the impact that a witness' demeanor has upon the reception of his testimony, makes the prediction and control of the witness' presentational style issues of importance to the practicing attorney. ${ }^{3}$

To aid attorneys in this aspect of their trial responsibility, works on trial tactics enumerate the major stylistic variations that may arise in testimony and speculate on the possible effects of various styles on the reception of evidence by a judge or jury. ${ }^{4}$ Although discussions of this sort are no doubt helpful in conveying the wisdom of accumulated advocacy experience, the development of techniques in the social sciences and the increasing application of these techniques to the study of courtroom behavior provide a more efficient and accurate means for gathering information about styles of testifying, for drawing conclusions about the effects of style on the reception of testimony by the jury and, ultimately, for developing recommendations about appropriate judicial responses to presentational phenomena. Using methods developed in anthropology, linguistics, psychology and other social sciences for the study of just such issues as those involved in testimonial style, ${ }^{5}$ it is

3. A critical part of a speaker's presentational style is physical behavior, which provides the background for the words being uttered. Some aspects of this background behavior are tangible, such as gestures, facial expressions and body language, while other, intangible aspects are subsumed by such terms as "presence" and "bearing." As is obvious from experience, an unimpressive appearance and inappropriate behavior can destroy the value of testimony that is highly credible in terms of raw content, while a convincing demeanor may give an appearance of substance to testimony that may in fact be devoid of meaning. This was recently illustrated in Looking Guilty, a segment of CBS News "Sixty Minutes" (Oct. 29, 1978) which depicted a criminal defendant being instructed on techniques by which he could enhance his credibility at trial.

In dealing with the demeanor of witnesses, the rule that the,courts have applied without exception is that the trier of fact may consider and attach whatever significance it chooses to such demeanor evidence. See, e.g., Mitsugi Nishikawa v. Dulles, 235 F.2d 135, 140 (9th Cir. 1956), rev'd on other grounds, 356 U.S. 129 (1958); Broadcast Music, Inc. v. Havana Madrid Restaurant Corp., 175 F.2d 77 (2d Cir. 1949); Gilliams v. Waltsons Corp., 105 N.H. 373, 201 A.2d 107 (1964); People v. Carter, 37 N.Y.2d 234, 333 N.E.2d 177, 371 N.Y.S.2d 905 (1975).

Indeed, in California counsel may request that the following jury instruction be given concerning the credibility of witnesses:

You are the sole and exclusive judges of the credibility of the witnesses who have testified in this case.

In determining the credibility of a witness you may consider any matter that has a tendency in reason to prove or disprove the truthfulness of his testimony, including but not limited to the following:

His demeanor while testifying and the manner in which he testifies . . . .

CALIForNia JURY INSTRUCTIONS: CiviL 28 (6th rev. ed. P. Richards ed. 1977) (emphasis added).

4. See Techniques for Conducting Cross Examination in F. BAILEY \& H. ROTHBLATT, supra note 1, §§ 180-198; R. KEETON, supra note 1, at 30-42 (preparing witnesses for direct examination).

5. See, e.g., Aronson \& Carlsmith, Experimentation in Social Psychology, in 2 HANDBOoK 
possible to generate empirical answers to these questions of longstanding interest to the legal profession.

This Article presents the findings of an empirical study developed by the authors to determine the influence of presentational style on juries functioning as decision makers and analyzes the significance of these findings. The Article concludes with proposals for dealing with the effects of presentational style on the process of communication in the courtroom.

\section{The Studies}

Recent years have seen an increasing interest among social scientists in studying the American legal system and an increasing willingness in the legal community to make use of the results of social science studies. For the most part, these studies have investigated issues relevant to judicial procedure and substantive issues of trial law. ${ }^{6}$ It is in the area of procedural law that social science research appears to have had its greatest impact upon legal developments. ${ }^{7}$ Although social science techniques, especially those of anthropology, have been applied to the study of speech styles in legal systems other than our own, ${ }^{8}$ the study of language used in American courtrooms is only beginning.

The study of witness styles is a natural extension of recent sociolinguistic research on styles of speaking in nonlegal contexts. This re-

of Social Psychology 1-79 (G. Lindzey \& E. Aronson eds. 1968). But see Bermant, McGuire, McKinley \& Salo, The Logic of Simulation in Jury Research, 1 CrIM. JuSTICE AND BEHAVIOR 224 (1974).

6. See H. Kalven \& H. Zeisel, The American Jury (1966); J. Thibaut \& L. Walker, Procedural Justice: A Psychological Analysis (1975); Lind, Thibaut \& Walker, A CrossCultural Comparison of the Effect of Adversary and Inquisitorial Processes on Bias in Legal Decisionmaking, 62 VA. L. Rev. 271 (1976); Lind, Thibaut \& Walker, Discovery and Presentation of Evidence in Adversary and Nonadversary Proceedings, 71 MICH. L. Rev. 1129 (1973); Thibaut, Walker \& Lind, Adversary Presentation and Bias in Legal Decisionmaking, 86 HARv. L. REV. 386 (1972). See The Disputing Process: Law in Ten Societies (L. Nader \& H. Todd eds. 1978) and Rosen, The Anthropologist as Expert Witness, 79 AM. ANTHRopozogist 555 (1977), for studies by anthropologists involving topics concerning the American legal system.

7. See, e.g., Ballew v. Georgia, 435 U.S. 223 (1978); Colgrove v. Battin, 413 U.S. 149, 158-59 (1973); Apodaca v. Oregon, 406 U.S. 404 (1972); Johnson v. Louisiana, 406 U.S. 356 (1972); Williams v. Florida, 399 U.S. 78 (1970). See also Padawer-Singer, Singer \& Singer, An Experimental Study of Twelve versus Six Member Juries Under Unanimous versus Non-unanimous Decisions, in Psychology In THE Legal Process (B. Sales ed. 1977). The issues of jury size and unanimity of verdicts are the subjects in each of the cited cases and of the empirical studies conducted by Singer.

8. The best known of these studies is Frake, Struck by Speech: The Yakan Concept of Litigation, in LAW IN CUlTURE AND SOCIETY 147 (L. Nader ed. 1969). Two recently published collections of articles also contain many examples of speech styles appropriate to legal contexts in non-Western societies. See M. Bloch, Political Language and Oratory in Traditional Society (1975); W. O'Barr \& J. O'Barr, Language and Politics (1976). 
search has revealed that, across a wide variety of situations, it is possible to distinguish definite styles of speaking and to trace these styles to the social background and the immediate social surroundings of the speaker. ${ }^{9}$ Other studies, again in nonlegal contexts, have shown that listeners form impressions of speakers based on the way they speak as well as on what they say. ${ }^{10}$ Some such studies, for example, have demonstrated that an individual's style of speaking can influence the degree to which others accept his arguments. ${ }^{11}$ Encouraged by these findings, the authors designed a research program to investigate the influence of courtroom presentational style on jury impressions of witnesses. $^{12}$

9. See, e.g., W. Labov, The Social Stratification of English in New York City (1966); W. Labov, Sociolinguistic Patterns (1972); Fischer, Social Influences on the Choice of a Linguistic Variant, 14 WORD 47 (1958), reprinted in LANGUAGE IN CULTURE AND SOCIETY 483 (D. Hymes ed. 1964).

10. Social scientists have shown that the same information presented in different speech styles may be perceived and evaluated differently. In a classic experiment, W. Lambert and associates asked bilingual Montrealers to speak once in English and once in French in a conversation recorded for experimental study. Lambert's experimental subjects judged the French speaker significantly more negatively on most dimensions than they did the same speaker when repeating the same information in English. See Lambert, Hodgson, Gardner \& Fillenbaum, Evaluational Reactions to Spoken Languages, 60 J. ABNORMAL \& Soc. PSYCH. 44 (1960).

11. H. Giles \& P. Powesland, Speech Style and Social Evaluation (1975), is a comprehensive review of social scientific studies of the influence of different styles of language such as accents, use of one or another language in bilingual societies, and educated or uneducated varieties of language on social evaluation of speakers. Despite the large number of studies conducted by psychologists in this general area, Giles and Powesland concede that almost nothing is known about the effects of different language varieties in legal contexts:

Almost certainly, nonstandard usage can also affect forensic situations such as police and courtroom decision-making. . . . For example, when members of the public are stopped in the street or on the highway by the police for inquiries, do standard speakers undergo a less severe interrogation than nonstandard users of the language? Is evidence by standard speakers generally regarded by courts as more reliable and substantial than evidence given by nonstandard speaking witnesses? Are juries prejudiced by the speech style of accused persons? How does the speech style of a lawyer affect his advocacy? At present there are no answers to these questions.

Id. 111 (emphasis added).

12. Although it is beyond the scope of this Article, an equally widely recognized linguistic problem is that of the presentational style of counsel. By virtue of his obvious position as an intermediary between the legal authority of the state and the lay public, and his presumed command of legal language, the lawyer may assume an aura of quasi-judicial authority in the eyes of the jury. The jury often hears that a lawyer is an "officer of the court," suggesting an intermediate position between the court and the lay public. This role is confirmed in a variety of other obvious ways: the lawyer erjoys a unique freedom of movement in the courtroom; he controls the flow of information; he is able simultaneously to converse with the judge in the obscure language of the law and with the jurors in everyday English. Even in dress, the lawyer is likely to occupy an intermediate position between the archaic formality of the judge and court officers and the casual appearance typical of jurors. Accordingly, opinions and conclusions expressed by the lawyer may often be perceived as having some official standing. Resort by counsel to stylistic extremes thus creates a particularly serious danger that the jury will be diverted from its theoretical role of evaluation of the facts and induced to engage in speculation and emotional reaction. 


\section{A. The Discovery of Witness Styles.}

In order to discover the various testimony styles that occur frequently in trials, the authors conducted an extensive study of the speaking styles of actual courtroom witnesses. With the permission of the court, all criminal trials in the Superior Court of Durham County, North Carolina during the summer of 1974 were tape recorded, ${ }^{13}$ yielding more than 150 hours of taped testimony and other courtroom speech. At the same time the recordings were made, observers trained both in anthropological field techniques and in the law made notes concerning the trials so that the audio tape recordings could be related easily to the context and general legal background of each trial. ${ }^{14}$

The tape recordings and trial notes subsequently were analyzed from the perspective of sociolinguistics to identify speech styles and the social contexts with which they were correlated. These analyses revealed a number of consistent linguistic patterns that appeared frequently in the observed testimony. ${ }^{15}$ The research focused on four of these patterns: (1) the use of "powerful" and "powerless" speech by witnesses; (2) the delivery of testimony in the "narrative" and "fragmented" styles; (3) the use of "hypercorrect" speech by witnesses; and (4) the speech behavior of lawyers and witnesses in instances of simultaneous speech and interruptions in testimony. The results of this research are presented below.

\section{B. Style and Reaction to Testimony.}

1. "Powerful" Versus "Powerless" Speech Styles in Witness Testi-

13. Our recording equipment was the same as that used regularly by the court reporter. Its presence appeared to have no disruptive effect on court proceedings. Criminal trials on a variety of misdemeanor, felony and capital charges were taped. The parties came from a variety of social, economic, ethnic and linguistic backgrounds. Use of the tapes has been restricted to those directly involved in the research project, and every effort has been made to protect the anonymity of those involved in the trials.

14. Another technique used to investigate stylistic differences in the courtroom was the questioning of attorneys about their perceptions of presentational styles and the effects of such styles on the impact of testimony. Unfortunately, although the interviewed lawyers often expressed the opinion that such factors were important, they could seldom identify with any precision those styles they thought significant. This is hardly surprising, since the styles ultimately discovered in the trial tapes often involved quite subtle variations in the use of particular features of speech. It should be noted that the lawyer's difficulty in discriminating among such subtle variations is another reason for using empirical techniques, such as those described here, in addition to the intuitive methods that traditionally have dominated the investigation of trial tactics. See generally O'Barr \& Lind, Ethnography and Experimentation-Partners in Legal Research, in 2 PERSPECTIVES IN LAW AND Psychology (B. Sales ed.) (forthcoming).

15. We were influenced to a significant degree in our choice of topics for detailed study by the advice offered in trial practice manuals concerning effective stylistic techniques in courtrooms. See authorities cited at note I supra. 
mony. One empirically derived "style" of courtroom speech was of particular interest not only because of its frequent occurrence in the observed trials but also because it has been the subject of previous comment both by social scientists ${ }^{16}$ and by the courts. ${ }^{17}$ This style is characterized by the frequent use of words and expressions that convey a lack of forcefulness in speaking. Among the specific features of this style is the abundant use of hedges (prefatory remarks such as "I think" and "It seems like"; appended remarks like "you know"; and modifiers such as "kinda" and "sort of"); hesitation forms (words and sounds that carry no substantive meaning but only fill possible speech pauses, such as "uh," "um" and "well"); polite forms (for example, the use of "sir" and "please"); and question intonation (making a declarative statement with rising intonation so as to convey uncertainty). An additional feature of this style is the frequent use of intensifiers (for example, "very," "definitely" and "surely") - words that, though they normally increase the force of an assertion, may be so overused that they suggest that the speaker is not to be taken seriously in their absence. These features tended to occur together in the taped testimony, comprising a definite style in the delivery of testimony.

Once this particular style of witness speech had been identified, its incidence and the social contexts correlated with its use had to be ascertained. A review of the tapes and notes of the trials revealed that witnesses of low social status-the poor and uneducated-were most likely to use this style of testimony. Female witnesses used the style more frequently than men. Because the incidence of use of this style was more common among those with little social power, it was termed the "powerless" style of testimony. ${ }^{18}$

16. For example, Robin Lakoff, a linguist, maintains that a style of speaking similar to that studied here is characteristic of many American women. She terms this phenomenon "woman's language." See R. Lakoff, Language and Woman's Place (1975).

17. See, e.g., Covey v. State, 232 Ark. 79, 82-83, 334 S.W.2d 648, 651 (1960); Quiroz v. Stuzyane, 124 Cal. App. 2d 534, 536-38, 269 P.2d 103, 104-05 (Cal. App. 1954); Law v. Hemmingsen, 247 lowa 855, 858-60, 76 N.W.2d 783, 785-86 (1956); Steele v. Woods, 327 S.W.2d 187, 197 (Mo. 1959); Masonic Home of Mo. v. Windsor, 338 Mo. 877, 880-82, 92 S.W.2d 713, 715-17 (1936). In each of these cases, various elements of the "powerless" style, see text following note 17, were present. In each instance the court, without analysis, made a conclusory statement to the effect that the witness' apparent lack of certainty was merely a partial index of credibility, to be weighed by the jury.

18. A detailed analysis of the types of witnesses who more frequently use "powerless" language is contained in O'Barr \& Atkins, "Women's Language" or "Powerless Language"?, in LANGuage ANd Women's Lives: A Feminist Perspective (R. Borker, N. Furman \& S. McConnellGinet eds.) (forthcoming). The factors associated with the likelihood of a witness using "powerless" language were not exhaustively investigated in the study that is the subject of this Article. The study was more concerned with determining the effect of variations in the manner in which testimony is presented. 
In marked contrast to the powerless style is a more straightforward manner of testifying. Those witnesses in the taped trials whose social status in court was higher-for example, well-educated, white collar men and expert witnesses of both sexes - tended to use a style that exhibited relatively few features of the powerless style. The difference between the testimony used by witnesses testifying in a "powerful" style as opposed to the "powerless" style is best illustrated by examples of the same substantive testimony given by witnesses speaking in the two different styles:

Q. Approximately how long did you stay there before the ambulance arrived?

A. (Powerless): Oh, it seems like it was about, uh, twenty minutes. Just long enough to help my friend, Mrs. Davis, you know, get straightened out.

(Powerful): Twenty minutes. Long enough to help get Mrs. Davis straightened out.

Q. Now how long have you lived in this town?

A. (Powerless): All my life, really. (Powerful): All my life.

Q. You're familiar with the streets?

A. (Powerless): Oh yes. (Powerful): Yes.

Q. You know your way around?

A. (Powerless): Yes, I guess I do. (Powerful): Yes.

Once anthropological and linguistic procedures had been used to identify the powerful and powerless styles as forms of in-court testimony, the methods of experimental social psychology were used to investigate the consequence of each style on the reception of the testimony by the jury. That is, having found that these two styles exist in actual courtroom testimony, the next step was to determine whether witnesses using one style were in fact perceived differently than witnesses using the other style. This determination involved exposing a substantial number of people to versions of testimony that differed only in testimonial style. Because it was possible to assure with a high degree of certainty that there were no a priori differences between those individuals who heard one version of the testimony and those who heard another version, ${ }^{19}$ any differences in perception that were observed after the testimony had been presented could be attributed un-

19. The key to this assurance that no a priori differences exist between the groups exposed to various experimental conditions is the random assignment of individuals to the conditions. Because the assignment procedure is a random process, there can be no systematic differences in the individuals assigned to particular conditions. Random assignment permits the use of statisticaldecision procedures in assessing the likelihood that observed differences are in fact the result of differences between the experimental conditions to which the participants are exposed. See D. 
equivocally to stylistic differences in the testimony.

A social psychology experiment was a logical choice for the continuation of the investigation because it permits unambiguous testing of the capacity of a social factor to cause specific reactions in those exposed to it. ${ }^{20}$ The logic of social-psychological experimentation demands that the various test conditions to which experimental participants are exposed differ only in terms of the factors under examination. It was necessary, therefore, that the experiment present the participants with testimony that, in all conditions, contained exactly the same substantive information.

To accomplish this the authors located a segment of powerless style testimony in the original trial tapes. ${ }^{21}$ This testimony was edited slightly to make it more suitable for use in the experiment. ${ }^{22}$ The testimony was then recorded on audio tape with actors playing the parts of lawyer and witness. The actors strove to replicate as closely as possible the speech characteristics found in the original testimony. A second recording was then made using the same actors. In this recording, however, most of those features that characterize the powerless style were omitted, thereby producing an example of testimony in the powerful style. The powerful and powerless experimental testimony differed only in characteristics related to the speech style used by the witness. In both samples of testimony, exactly the same factual information was presented by the same witness.

The first two columns of Table 1 present the results of linguistic analyses of the two experimental testimony tapes. As the table clearly shows, the two tapes differed markedly on each of the features that distinguish the two styles. These differences produced the conditions

Campbell \& J. Stanley, Experimental and Quasi-Experimental Designs for Research (1963).

20. There are, of course, costs associated with the otherwise desirable features of a social psychology experiment. Removing the study from the courtroom to achieve the necessary control conditions introduces some doubt as to whether the same processes that actually occur in the courtroom were observed. The authors exercised the tightest controls possible on the experimental situation-allowing only speech style to vary. See Bermant, McGuire, McKinley \& Salo, supra note 5 .

21. The original trial from which the testimony was taken was a manslaughter case. The testimony was presented to experimental participant-jurors as part of a civil suit for damages. The authors transformed the case from criminal to civil for two reasons: to minimize the possibility of any strong reactions on the parts of participant-jurors to the terms "criminal" and "manslaughter," both of which tend to be more emotionally laden terms than "civil" and "recovery of damages," and to allow inquiry about variable amounts of monetary awards as opposed to the binary choice between "guilty" and "not guilty" in the criminal context.

22. Specifically, the names, dates and locations mentioned in the original testimony were changed so as to fulfill the promise to the court that the privacy of those involved in the actual trials would be protected. Since they tended to divert attention, attorney objections and the testimony to which the objections were addressed were also removed. 
Table 1

COMPARISON OF LINGUISTIC CHARACTERISTICS OF THE FOUR POWERFUL/POWERLESS TAPES

\begin{tabular}{|c|c|c|c|c|}
\hline & \multicolumn{2}{|c|}{ Female Witness } & \multicolumn{2}{|c|}{ Male Witness } \\
\hline & Powerful & Powerless & Powerful & Powerles \\
\hline Hedges $^{a}$ & $2 \mathrm{~g}$ & 22 & 2 & 21 \\
\hline Hesitation forms ${ }^{b}$ & 13 & 73 & 18 & 51 \\
\hline W asks $L$ question ${ }^{c}$ & 2 & 5 & 2 & 6 \\
\hline Use of "sir" by Wd & 0 & 3 & 0 & 4 \\
\hline Intensifierse & 0 & 35 & 0 & 31 \\
\hline Running time of tape $\mathrm{e}^{f}$ & $7: 31$ & $9: 30$ & $7: 43$ & $9: 39$ \\
\hline
\end{tabular}

a Forms that reduce the force of assertion by allowing for exceptions or avoiding rigid commitments such as sort of, a little, kind of, etc.

b Pause fillers such as $u h, u m, a h$, and meaningless particles such as oh, well, let's see, now, so, you see, etc.

c Use of question intonation in response to lawyer's questions, including rising intonation in normally declarative contexts (e.g., "thirty?, thirty-five?"), and questions asked by witness of lawyer such as "What do you mean?"

d Assumed to be indications of more polite speech.

c Forms that increase or emphasize the force of assertion such as very, definitely, very definitely, surely, such $a$, etc.

$f$ Time given in minutes and seconds.

$g$ The figures represent the number of features in each category present in the tapes.

needed to test the effects of speech style on reactions to a witness. To increase the applicability of the results of the experiment, however, a second factor was introduced.

The original testimony on which the experimental tapes were based was delivered by a female witness. To have conducted the experiment only with a female witness would have severely restricted the conclusions that might be drawn. To avoid the situation where the particular effects of the speech style factor were restricted to one $\operatorname{sex}^{23}$ the process used both a female and a male as witnesses. All four tapes thus produced presented the same information. As Table 1 indicates, the intended differences between powerful and powerless styles are present in all four experimental tapes. ${ }^{24}$ Once the four experimental tapes had

23. The use of witnesses of both sexes was deemed especially important in the study of the powerful and powerless styles since other researchers, e.g., R. LAKOFF, supra note 16, have asserted that the powerless style is characteristic of female speech in a variety of situations, while the powerful style is characteristic of male speech. In fact, the authors found instances of both styles among male and female witnesses in the actual trials they taped.

24. It will be noted from Table 1 that the powerful versions of the testimony taped by the male and female actors are quite similar. The powerless tapes, however, contain some important 
been produced, it was possible to proceed with the experimental test of the results of the two styles.

Ninety-six undergraduates at the University of North Carolina at Chapel Hill participated in the experiment. ${ }^{25}$ The participants reported to the experimental laboratory in groups of five to seven at a time. Upon their arrival they were given written instructions describing the experiment. These instructions, also read aloud by the experimenter, explained that participants would hear a segment of testimony from an actual trial. The instructions then briefly outlined the details of the case and the major issues to be decided.

The case involved a collision between an automobile and an ambulance. The patient in the ambulance, already critically ill and en route to a hospital, died shortly after the collision. The participants in the experiment were told that the patient's family was suing the defendants (both the ambulance company and the driver of the automobile) to recover damages for the patient's death. The participants were also told that the witness under examination in the trial segment was a neighbor and friend who had accompanied the patient in the ambulance and was therefore present during the collision. The participants were informed that they would be asked questions about their reactions to the testimony after listening to the trial segment. Note taking was not allowed. ${ }^{26}$

differences between the male and female versions. In frequency of powerless characteristics, the male version has relatively fewer instances of the powerless features. It contains, for example, fewer hesitations and intensifiers than the female version. In general, the male powerless tape contains many elements of powerless language, but it is a less extreme variant of the style than that utilized by the original witness and replicated in the female experimental version. These differences between the male and female powerless versions were intentionally programmed in making the experimental tapes because a faithful replication of the original female witness' speech style and powerless mannerisms-although suitable for a female witness-were not within the normal range of acceptable male verbal usage.

25. Of the 96 participants, 46 were male and 50 were female. The authors recognize the important question of the degree to which results obtained from experimental studies using students as subjects can be generalized to the public at large. Although there are many differences between the average student and the typical juror, it was appropriate to begin experimental research about the effects of speech style on legal decision making with student participants. The use of students in social-psychological experiments is, of course, a widely accepted practice, and it is important to note that in many instances replication of experiments with widely different subject populations has frequently found the same results. See Lind, Thibaut \& Walker (1976), supra note 6; Thibaut, Walker \& Lind, supra note 6. The use of students in the initial stages of research is further justified by the fact that only the basic question of whether testimony delivered in different presentational styles is evaluated differently was being asked. Further studies evaluating the extent and nature of those differences should employ a subject population more closely approximating actual jurors.

26. This follows the practice in most jurisdictions. See Note, Taking Note of Note-Taking, 10 Colum. J.L. \& SoC. Prob. 565 (1974). 
The participant-jurors then listened to one of the four experimental tapes described above. After the participants had heard the testimony, the experimenter distributed a questionnaire concerning their reactions to the case and to the individuals involved. The responses to these questions led the authors to their conclusions, discussed below, concerning the effects of testimonial style on the reception of information by jurors. ${ }^{27}$

2. Results of the Experiment. Table 2 shows the average ratingscale responses compiled from five questions about the witness. For

Table 2

AVERAGE RATING OF WITNESSES USING POWERFUL VERSUS POWERLESS TESTIMONY STYLES

\begin{tabular}{|c|c|c|c|c|}
\hline \multirow[b]{2}{*}{ Question Asked } & \multicolumn{2}{|c|}{ Female Witness } & \multicolumn{2}{|c|}{ Male Witness } \\
\hline & Powerful & Powerless & Powerful & Powerless \\
\hline $\begin{array}{l}\text { "How convincing in general } \\
\text { was this witness?" }\end{array}$ & $3.00^{\mathrm{a}}$ & 1.65 & 3.52 & 2.09 \\
\hline $\begin{array}{l}\text { "To what extent did you believe the } \\
\text { witness was telling the truth?" }\end{array}$ & 3.70 & 1.88 & 4.24 & 2.86 \\
\hline $\begin{array}{l}\text { "To what extent do you feel that the } \\
\text { witness was competent?" }\end{array}$ & 2.61 & 0.85 & 2.44 & 0.18 \\
\hline $\begin{array}{l}\text { "To what extent do you feel that the } \\
\text { witness was intelligent?" }\end{array}$ & 2.57 & -0.23 & 1.80 & 0.18 \\
\hline $\begin{array}{l}\text { "To what extent do you feel that the } \\
\text { witness was trustworthy?" }\end{array}$ & 3.04 & 1.65 & 3.48 & 2.00 \\
\hline
\end{tabular}

a The numbers represent the rating each witness received on a +5 to -5 scale. +5 was the highest positive response that could be given to the question asked, and -5 was the most negative response to the question.

27. The participant-jurors were asked to respond to the questionnaire as individuals rather than as a group. Several reasons justify the study of individual rather than group reactions. When we began this research, there were no previous studies of the effects of speech style on legal decision making. See H. GILES \& P. Powesland, supra note 11, at 111 . Thus, as a first step in understanding how speech style factors might ultimately affect legal decision making, the authors posed the question of what, if any, effects "powerful" versus "powerless" language would have on individuals who were asked to make legal judgments. A subsequent stage in this research calls for the study of whether such factors, demonstrated through the experimental research reported in this Article to have significant effects on individuals, operate in the same way in group deliberative contexts. Although there may be differences between the effects of speech style in individual as opposed to group decision making contexts, several studies by social scientists have shown that individual judgments are highly predictive of group behavior. Specifically, it has been determined that initial judgments of jurors appear to be the predominant factor in determining the final verdict of the entire jury. See Davis, Bray \& Holt, The Empirical Study of Social Decision Processes in Juries, in Law, Justice, and the Individual in Society: Psychological and Legal Issues 326 (J. Tapp \& F. Levine eds. 1977); Davis, Group Decision and Social Interaction: A Theory of Social Decision Schemes, 80 PsYcH. REV. 97 (1973). 
each of these questions, a rating of " +5 " indicates a very strong positive response to the question, while a rating of " -5 " indicates a strong negative response. The effects of the testimonial style of the female witness may be seen by contrasting the first and second columns of the table. The results for the male witness are presented in the third and fourth columns of the table.

Statistical analyses ${ }^{28}$ confirm the patterns of testimony-style influences seen in the table. These analyses indicate, with a generally high degree of certainty, that in comparison to those who heard the female witness give her testimony in the powerless style, those who heard her use the powerful style indicated that they believed the witness more $(p$ $<.01$ ), found her more convincing $(p<.06)$, and thought that she was more competent $(p<.01)$, more intelligent $(p<.001)$ and more trustworthy $(p<.02)$. In short, the female witness made a much better impression when she used the powerful style than when she used the powerless style.

The same pattern of results was found in the comparison of the male witness' powerful and powerless testimony. Again, the statistical analyses demonstrate, with high certainty, that participants who heard the powerful style testimony responded more positively to questions regarding the believability of the male witness $(p<.05)$ and the extent to which they were convinced by his testimony $(p<.05)$. As with the female witness, participants who heard the male witness testify in the powerful style thought him more competent $(p<.001)$, more intelligent $(p<.005)$ and more trustworthy $(p<.02)$ than did those who heard the witness testify in the powerless style. Thus, as the experiment clearly demonstrates for both male and female witnesses, the use of the powerless style produces consistently less favorable reactions to a witness than does the use of the powerful testimony style.

3. Narrative Versus Fragmented Styles of Testimony. Writings on trial tactics and the testimony that the authors recorded and analyzed suggested a second topic for experimentation. Some of the recorded testimony was characterized by relatively infrequent questions

28. The significance of the results reported in this section was assessed by the appropriate multivariate or univariate analysis-of-variance technique. A difference between two experimental conditions is tested for statistical significance by comparing the magnitude of the difference to the variation within each condition. The difference is said to be "significant" if it would occur less than five times out of a hundred by chance alone (written as $p<.05$ ). Smaller values of " $p$ " provide greater assurance that the difference was not the result of chance. Sometimes the $p$ values of .10 are accepted as significant, meaning that the probability of occurrence by chance alone is 10 times out of 100 . 
from the lawyer and long narrative answers by the witness. Other testimony was characterized by frequent questions from the lawyer and brief answers by the witness. The same evidence could be presented in either the "narrative" or the "fragmented" form. The following exchanges exemplify the differences between these two testimonial styles:

Excerpt of Testimony in Narrative Style:

Q. Now, calling your attention to the 21st day of November, a Saturday, what were your working hours?

A. Well, I was working from, uh, 7 a.m. to 3 p.m. I arrived at the store at 6:30 and opened the store at 7.

Excerpt of Testimony in Fragmented Style:

A. Well, I was working from 7 to 3 .

Q. Was that 7 a.m.?

A. Yes.

Q. And what time that day did you arrive at the store?

A. $6: 30$.

Q. 6:30. And did, uh, you open the store at 7 o'clock?

A. Yes, it has to be opened.

Legal tacticians have advised that the credibility of a witness can be enhanced on direct examination if the lawyer allows and encourages the witness to testify in the narrative style. ${ }^{29}$ While this point might seem obvious as an intuitive matter, the authors suspected that the use of one style or the other might have differing, more complex effects. Specifically, because the narrative and fragmented styles entail differences in the speech behavior of the lawyer, as well as that of the witness, it seemed that both judges and jurors might interpret the use of a narrative or fragmented style as indicating the lawyer's own evaluation of the witness. For example, if those hearing testimony believe that its style is determined by the lawyer, they may believe that use of a narrative style indicates the lawyer's faith in the witness' competence. Similarly, when the witness uses a fragmented style, presumably under the direction of the lawyer, the lawyer may be thought to consider the witness incompetent. ${ }^{30}$

To test these assertions of legal tacticians as well as the authors' own suspicions, an experiment similar to that used to investigate the effects of powerful and powerless speech was conducted. Listeners heard tape-recorded reenactments of direct testimony in a criminal trial. The tapes presented the same substantive evidence in either the narrative or the fragmented style. ${ }^{31}$ As in the first study, this experi-

29. E.g., A. MoRriLl, supra note $1, \S 3.7($ b), at 34 .

30. See note 12 supra.

31. The actual witness was a female convenience-store clerk who was the victim of an armed 
ment examined style effects in the testimony of both male and female witnesses. This study also sought to determine whether listeners with legal training were less likely to be affected by differences in style than were listeners without legal training. Therefore, law students as well as undergraduate students participated. ${ }^{32}$

The study assessed the participants' beliefs concerning how competent the lawyer thought the witness to be and their own evaluations of the competence of the witness. Table 3 presents the average ratings in response to questions on these issues.

Table 3

AVERAGE RATINGS OF WITNESSES USING NARRATIVE VERSUS FRAGMENTED TESTIMONY STYLES

\begin{tabular}{|c|c|c|c|c|c|}
\hline \multirow[b]{2}{*}{ Question Asked } & \multirow[b]{2}{*}{$\begin{array}{l}\text { Sex of } \\
\text { Witness }\end{array}$} & \multicolumn{2}{|c|}{ Undergraduates } & \multicolumn{2}{|c|}{ Law Students } \\
\hline & & $\begin{array}{c}\text { Narrative } \\
\text { Style }\end{array}$ & $\begin{array}{l}\text { Fragmented } \\
\text { Style }\end{array}$ & $\begin{array}{c}\text { Narrative } \\
\text { Style }\end{array}$ & $\begin{array}{l}\text { Fragmented } \\
\text { Style }\end{array}$ \\
\hline \multirow{2}{*}{$\begin{array}{l}\text { "To what extent does } \\
\text { lawyer think the wit- } \\
\text { ness is competent?" }\end{array}$} & Male & $1.37 \mathrm{a}, \mathrm{b}$ & -1.20 & 0.27 & 0.91 \\
\hline & Female & 1.21 & 0.60 & 3.40 & 0.82 \\
\hline \multirow{2}{*}{$\begin{array}{l}\text { "To what extent do } \\
\text { you think the wit- } \\
\text { ness is competent?" }\end{array}$} & Male & 1.58 & -0.29 & 0.45 & 0.00 \\
\hline & Female & 0.21 & 0.96 & 2.40 & 0.18 \\
\hline
\end{tabular}

a The numbers represent the rating each witness received on a +5 to -5 scale. +5 was the highest positive response that could be given to the question asked, and -5 was the most negative response to the question.

b Italicized numbers in the table indicate that the differences between ratings of speakers using narrative versus fragmented styles were substantial, i.e., they approached or surpassed statistical significance as described in note 28 supra.

Although the results are rather complex, several conclusions can be drawn. First, the use of the narrative or fragmented style, acting in combination with the sex of the witness and legal training, did lead to significant differences in estimates of how competent the lawyer thought the witness to be $(p<.02)$ and to significant differences in how competent the experimental participants themselves thought the wit-

robbery. At the trial, she seldom volunteered more than one or two short sentences at a time, thereby forcing the prosecutor to prod her constantly with questions such as "And then what happened?" in order to elicit her full testimony.

32. This approach was used in a rudimentary effort to assess whether the overall conclusions provided by the study would be equally applicable where a judge rather than a jury sat as the trier of fact. Available resources could not provide actual judges or lawyers as participants. Law students were considered the best approximation. 
ness to be $(p<.03){ }^{33}$ Second, in those situations where there were substantial differences in reactions to the two styles (indicated by the italicized ratings in the table), the narrative style led to more favorable responses than did the fragmented style. Third, subjects both with and without legal training were sensitive to differences in testimonial style. Finally, as Table 3 suggests, further analyses of the data resulted in the determination that it is indeed likely that the effects of the styles on the participants' own evaluations of the witness were based on the participants' interpretations of the lawyer's perception of the witness.

In general, the study shows that the use of either the narrative or the fragmented style does affect evaluations of the witness, with the narrative style often producing more favorable evaluations. Judicial folklore, as evidenced by the trial practice literature, is thus directly confirmed on this issue. Moreover, a precedent has been established for the point-by-point scientific investigation of trial theories that heretofore have been based solely on intuition. Finally, on a more subtle level, the study shows that listeners can be quite sophisticated in their interpretations of testimonial styles, using the style they hear to draw conclusions about the lawyer's perception of the witness.

4. Hypercorrect Speech in Testimony. Most of the testimony observed was considerably more formal than everyday conversation. This came as no surprise, a trial court being one of the most formal and intimidating situations that a witness is ever likely to confront. Some witnesses attempted to speak in a much more formal style than was their custom and, consequently, made frequent errors in grammar and vocabulary. Witnesses who used this "hypercorrect" style did not achieve the formal style intended, but instead spoke in a stilted and unnatural manner. ${ }^{34}$

Once these stylistic differences had been discovered, the authors decided to conduct a social-psychological experiment to test the effects

33. These $p$-values are based on the overall pattern of responses by all participants rather than those of any subgroup of participants.

34. The phenomenon of hypercorrect speech is prevalent in a variety of social contexts in which the speaker would feel compelled to "talk up" to his audience. See W. LaBov (1972), supra note 9.

The authors first noted the hypercorrect style in the speech of an assistant ambulance attendant. Although he had only minimal first aid training, he obviously wished to impress the court and jury with the depth of his medical knowledge. He sprinkled his speech with hypercorrect malapropisms presumably designed to promote his own importance: he invariably described "three days" as "seventy-two hours"; he described a person who had been knocked out as "comatose," although she had merely been unconscious; he characterized a slightly injured patient as "in a somewhat less than dire condition"; and, with respect to events he did not remember, he said he was "not cognizant" of them. 
of hypercorrect versus standard formal speech in testimony. Actors recreated, on tape, a segment of testimony in which a witness used the hypercorrect style. A second tape was then made in which the testimony was presented in the ordinary formal style. The witness was male on both tapes. Undergraduate participants listened to one of the two tapes and rated the witness in response to a number of questions. The results for some of these questions are presented in Table 4.

Table 4

RATING OF WITNESSES SPEAKING IN FORMAL AND HYPERCORRECT STYLES

\begin{tabular}{|c|c|c|}
\hline \multirow[b]{2}{*}{ Question Asked } & \multicolumn{2}{|c|}{$\underline{\text { Style }}$} \\
\hline & Formal & Hypercorrect \\
\hline "How convincing in general was this witness?" & $3.19 \mathrm{a}$ & 2.05 \\
\hline $\begin{array}{l}\text { "To what extent do you think the witness was } \\
\text { qualified to testify about the state of Mrs. } \\
\text { Davis' health before the accident?" }\end{array}$ & -0.62 & -3.24 \\
\hline $\begin{array}{l}\text { "Rate this witness on a scale from }-5 \text { (incom- } \\
\text { petent) to }+5 \text { (competent)." }\end{array}$ & 2.19 & -0.09 \\
\hline $\begin{array}{l}\text { "Rate this witness on a scale from }-5 \text { (not } \\
\text { intelligent) to }+5 \text { (intelligent)." }\end{array}$ & 0.43 & -1.29 \\
\hline
\end{tabular}

a The numbers represent the rating each witness received on a +5 to -5 scale. +5 was the highest positive response that could be given to the question asked, and -5 was the most negative response to the question.

As can be seen from the table, the witness was rated as significantly more convincing $(p<.05)$, more competent $(p<.01)$, more qualified $(p<.01)$ and more intelligent $(p<.01)$ when he used the formal style than when he used the hypercorrect style.

The obvious conclusion to be drawn is that jurors rapidly develop expectations about a witness' behavior on the basis of what they infer about his background and social status. When these expectations are violated by a witness who attempts to speak with an inappropriate degree of formality, the jurors' reaction is punitive. The ability of jurors to perceive subtle linguistic factors is thus once again confirmed and witnesses who fail to respect that ability may be doing so at their peril.

5. Interruptions and Simultaneous Speech. As a fourth study of the effects of stylistic differences in testimony, the authors turned their attention from direct examination situations to cross examination. Sometimes, most often in cross examinations, the testimony observed was characterized by verbal clashes between the lawyer and the witness. In these clashes the lawyer and witness frequently interrupted each other, appearing to vie for control of the testimony. With these 
interruptions often came simultaneous speech that reduced the issue of control to a question of which speaker could persevere longer. In any particular instance of simultaneous speech the lawyer might persevere while the witness ceased speaking, or the witness might dominate and the lawyer defer.

In this fourth experiment, undergraduate participants listened to recorded testimony in which two male actors, one playing the lawyer and one playing the witness, recreated several versions of a cross examination. In the control version of the testimony, there was no simultaneous speech-each speaker waited until the other had finished before beginning to speak. In the other three versions there was considerable simultaneous speech with each speaker interrupting the other. In one version the lawyer dominated, persevering in most of the simultaneous speech; in another version the witness dominated, persevering in most of the simultaneous speech; and in a third version, although both speakers interrupted one another frequently, neither speaker dominated-both persevered about equally often. All four versions of the testimony presented the same evidence. ${ }^{35}$

Table 5

AVERAGE RATING OF WITNESSES SPEAKING IN INTERRUPTION AND CONTROL SITUATIONS

\begin{tabular}{|c|c|c|c|c|}
\hline & Control Situation & & Interruptions & \\
\hline Rating Item & No interruptions & $\begin{array}{l}\text { Lawyer } \\
\text { dominates }\end{array}$ & $\begin{array}{l}\text { Witness } \\
\text { dominates }\end{array}$ & $\begin{array}{l}\text { Neither } \\
\text { dominates }\end{array}$ \\
\hline $\begin{array}{l}\text { Lawyer's control over } \\
\text { the testimony }\end{array}$ & $2.90^{3}$ & 1.23 & 1.70 & 2.30 \\
\hline $\begin{array}{l}\text { Witness had opportu- } \\
\text { nity to present evi- } \\
\text { dence }\end{array}$ & 1.10 & $-.10^{\mathrm{b}}$ & 1.50 & 1.60 \\
\hline $\begin{array}{l}\text { Lawyer was fair to wit- } \\
\text { ness } \\
\text { Lawyer was intelligent }\end{array}$ & $\begin{array}{l}1.40 \\
2.30\end{array}$ & .41 & $\begin{array}{l}2.00 \\
2.79\end{array}$ & $\begin{array}{l}1.25 \\
2.35\end{array}$ \\
\hline
\end{tabular}

a The numbers represent the rating each witness received on a +5 to -5 scale. +5 was the highest positive response, and -5 was the most negative response to the statement.

$b$ Italicized numbers in the table indicate that the differences between ratings of speakers in the "lawyer dominates" and "witness dominates" conditions are statistically significant, as explained in note 28 supra.

35. The experiment was based on a criminal trial in which a woman accused her alcoholic father of assaulting her mother. In the cross examination of the woman by defense counsel, situations in which either party completed a statement or question were the exception rather than the rule. 
After listening to the testimony, the juror-participants completed a questionnaire in which they were asked to rate the extent to which the lawyer controlled the testimony, the extent to which the witness had an opportunity to present his evidence and the extent to which the lawyer was fair to the witness. The participants were also asked a number of other questions, including how intelligent they thought the lawyer was. Table 5 presents the results of this study.

The participants' responses indicate that the different versions of the testimony did indeed affect their reactions. The ratings of perceptions of the lawyer's control revealed that, in comparison to the version containing no simultaneous speech, the lawyer was considered to have less control in all versions with simultaneous speech $(p<.03)$. That is, regardless of whether the lawyer or the witness dominated the simultaneous speech, or whether neither speaker dominated, participant-jurors felt that the lawyer was losing control when simultaneous speech occurred. Other significant differences in the ratings (italicized in the table) show that when the lawyer did engage in simultaneous speech and dominated the witness, the lawyer was seen as giving the witness less opportunity to present evidence, as being less fair to the witness and as being less intelligent.

Thus, this study suggests that it is best for a lawyer to avoid interruptions or simultaneous speech in the course of an examination, lest he or she be seen as losing control over the examination. When simultaneous speech does occur, the lawyer should not attempt to dominate the exchange. To do so creates an appearance of unfairness to the witness and leads to a strongly negative overall assessment of the lawyer by the jury.

\section{Possibilities for Limiting the Effects of Style.}

The four studies described above show that listeners' impressions of witnesses and lawyers are indeed influenced by the styles of speech used in testimony. Sometimes these presentational effects may serve the cause of justice, as when stylistic differences are actually related to whether a witness is telling the truth, or when a juror or judge uses stylistic clues to infer credibility. Sometimes, however, style effects may have less desirable consequences. For example, if it is correct to believe that the use of the powerful or powerless style is determined by the witness' social status and power in relation to the court, then the presentational effects observed in the powerful/powerless study suggest that low-status witnesses, by virtue of the way they speak, have less credibility and thus a lesser chance of a fair hearing than do high-status 
witnesses. This, of course, is not congruent with the ideals of American justice. ${ }^{36}$ Thus, a final study was undertaken in order to investigate whether style effects could be eliminated through some change in judicial procedures.

One way that the law attempts to control the use of information that is deemed unreliable is to instruct jurors to disregard such information. With this in mind, the powerful/powerless experiment discussed above was repeated-changing only the instructions given to the juror-participants. One third of the participants were given a standard charge. For a second third of the participants, the charge made general reference to the fact that witnesses might choose a particular way of speaking for reasons unrelated to the issues in the trial. The remaining participants received instructions that included not only the general reference to the use of various speech styles, but also included specific reference to many of the features of the powerless style, cautioning that these features need not indicate uncertainty or deceit. ${ }^{37}$ After receiving one of these three instructions (labeled standard, general style and specific style, respectively) the participants listened to one

36. Cf. Griffin v. Illinois, 351 U.S. 12, 19 (1956) ("There can be no equal justice where the kind of trial a man gets depends on the amount of money he has"). See also text accompanying notes $39-44$ infra.

37. The standard instruction read:

Now, members of the jury, you are the sole judges of the credibility of the witnesses and of their worthiness of belief. You may believe all, part, or none of what each witness testifies to. The weight to be given to the testimony of each witness is for your decision. In determining the weight to be given to the testimony of each witness as to whether he or she is to be believed, you should apply the same test of truthfulness that you would in your everyday affairs. You may consider the manner and appearance of the witness on the witness stand; the opportunity of the witness for seeing, hearing, knowing, and remembering that concerning which he or she testifies; the interest or lack of interest of the witness in the outcome of this case; any bias or prejudice which may be shown; any statement shown to have been made by a witness in the past which is consistent with the witness's testimony given here in court as may tend to corroborate or support his or her testimony; and any statement shown to have been made by a witness in the past which is inconsistent or contradictory with his or her testimony given here in court as may tend to impeach or discredit the testimony of the witness.

In addition to this standard information, the general style instruction added the following:

In preparing you for the consideration of the evidence to be presented in this trial, I call your attention, members of the jury, to recent studies which have shown that the way in which people speak may affect their believability. As you know, members of the jury, there are many different styles of speaking. Many of these are related to a person's background and origin and some are merely personal or idiosyncratic. It is for you, members of the jury, to determine whether or not these differences are related to the believability of a witness.

The specific style instruction, after including all of the above, further added:

For example, it has been shown that some people tend to begin their sentences by saying 'It seems to me . . . , or 'I think that . ..., or 'I believe ....,' or to end their sentences with rising intonation, or to phrase their answers in generally indefinite terms. Whether a particular witness is one of those generally cautious, non-committal individualls and is but following his or her usual way of expressing himself or herself, or whether he or she is a witness who really does not know what actually happened, or is deliberately evasive, is for you, members of the jury, to determine. 
of the four experimental tapes and then answered the same questionnaire that was used in the original powerful/powerless study. Table 6 presents the results of this study.

Table 6

AVERAGE RATING OF WITNESSES USING POWERFUL VERSUS POWERLESS TESTIMONY STYLES WITH DIFFERENT JURY INSTRUCTIONS

\begin{tabular}{|c|c|c|c|c|c|}
\hline \multirow[b]{2}{*}{ Question Askeda } & \multirow[b]{2}{*}{ Instructions } & \multicolumn{2}{|c|}{ Female Witness } & \multicolumn{2}{|c|}{ Male Witness } \\
\hline & & Powerful & Powerless & Powerful & Powerless \\
\hline $\begin{array}{l}\text { How convincing } \\
\text { in general was } \\
\text { witness? }\end{array}$ & $\begin{array}{l}\text { Standard } \\
\text { General Style } \\
\text { Specific Style }\end{array}$ & $\begin{array}{l}3.42^{\mathrm{b}} \\
3.00 \\
3.86\end{array}$ & $\begin{array}{r}.90 \\
1.00 \\
.90\end{array}$ & $\begin{array}{l}3.95 \\
3.00 \\
2.76\end{array}$ & $\begin{array}{r}1.74 \\
1.11 \\
.19\end{array}$ \\
\hline $\begin{array}{l}\text { To what extent } \\
\text { did you believe } \\
\text { witness? }\end{array}$ & $\begin{array}{l}\text { Standard } \\
\text { General Style } \\
\text { Specific Style }\end{array}$ & $\begin{array}{l}3.74 \\
3.74 \\
4.14\end{array}$ & $\begin{array}{l}1.48 \\
2.08 \\
2.00\end{array}$ & $\begin{array}{l}4.05 \\
3.09 \\
3.24\end{array}$ & $\begin{array}{l}3.11 \\
2.10 \\
1.24\end{array}$ \\
\hline $\begin{array}{l}\text { To what extent } \\
\text { was witness } \\
\text { competent? }\end{array}$ & $\begin{array}{l}\text { Standard } \\
\text { General Style } \\
\text { Specific Style }\end{array}$ & $\begin{array}{l}3.00 \\
1.83 \\
2.33\end{array}$ & $\begin{array}{l}.52 \\
.74 \\
.19\end{array}$ & $\begin{array}{l}2.37 \\
1.73 \\
1.94\end{array}$ & $\begin{array}{r}.68 \\
.74 \\
-.86\end{array}$ \\
\hline $\begin{array}{l}\text { To what extent } \\
\text { was witness } \\
\text { intelligent? }\end{array}$ & $\begin{array}{l}\text { Standard } \\
\text { General Style } \\
\text { Specific Style }\end{array}$ & $\begin{array}{r}1.95 \\
.91 \\
1.90\end{array}$ & $\begin{array}{l}-.38 \\
-.56 \\
-.66\end{array}$ & $\begin{array}{r}1.84 \\
.86 \\
1.12\end{array}$ & $\begin{array}{r}.63 \\
.47 \\
-1.00\end{array}$ \\
\hline $\begin{array}{l}\text { To what extent } \\
\text { was witness } \\
\text { trustworthy? }\end{array}$ & $\begin{array}{l}\text { Standard } \\
\text { General Style } \\
\text { Specific Style }\end{array}$ & $\begin{array}{l}3.58 \\
3.09 \\
2.76\end{array}$ & $\begin{array}{l}1.57 \\
1.83 \\
1.33\end{array}$ & $\begin{array}{l}3.63 \\
2.73 \\
2.71\end{array}$ & $\begin{array}{r}2.63 \\
1.53 \\
.71\end{array}$ \\
\hline
\end{tabular}

a The questions asked were identical to those described in Table 2.

b The numbers represent the rating each witness received on a +5 to -5 scale. +5 was the highest positive response, and -5 was the most negative response to the question.

As can be seen from the table, the overall results are similar to those of the initial powerful/powerless study. Whether the witness was male or female, he or she was thought to be less convincing $(p<.01)$, less believable $(p<.01)$, less competent $(p<.01)$, less intelligent $(p<$ $.01)$ and less trustworthy $(p<.01)$ when the powerless style was used when the same testimony was delivered in powerful style.

The instructions concerning speech styles led to no significant diminution of the style effects. As the table shows, powerless-speaking witnesses were viewed less favorably regardless of the instructions that the experimental participants received. This finding was not surprising, other studies having already shown that jurors seldom obey instructions to disregard what seems to them to be useful information. ${ }^{38}$ The present study confirms this and shows that judicial instructions and

38. E.g., Doob, Evidence, Procedure and Psychological Research, in PsYchology AND THE LAW 135 (G. Bermant, C. Nemeth \& N. Vidmar eds. 1976). 
procedures are unlikely to solve the problems raised in this research.

\section{CONCLUSIONS}

The results of the studies reported in this Article are important on two levels. On a practical level, the linguistic analysis of courtroom speech and the experiments investigating the effects of the powerful and powerless styles make a substantial contribution to trial practice theory. As was shown by the reactions of the participants in their function as legal decision makers, witnesses who speak in a straightforward, powerful and not unnaturally formal style, who testify with minimal assistance from the lawyer, and who resist efforts by opposing counsel to cut short their remarks will enhance their credibility because they will make more favorable impressions on the jury. Obviously, an attorney having two witnesses who can present the same evidence should rely more heavily on the witness whose natural style more closely approaches the optimal stylistic profiles defined by these experiments.

The results also strongly suggest that extensive pretrial witness education or coaching with respect to testimonial style may improve a witness' credibility in the eyes of the jury. For example, many of the problems pointed out by the studies of powerless and hypercorrect speech and of fragmented testimony might be avoided if counsel simply took time to make witnesses more relaxed and confident in testifying. This could be accomplished by having the witness rehearse his direct testimony several times before the actual trial. The problems illustrated by the interruption study can be minimized if the lawyer undertakes a conscious, on-going review of his own behavior. Finally, where the witness proves incapable of avoiding powerless, hypercorrect or fragmented speech, the lawyer may be able to compensate for the problems to which he is now alerted by giving the witness an opportunity to show, through the structure and content of his testimony, that he is indeed credible, competent and intelligent.

Even more important, however, are the general implications of the studies. The results suggest that relatively subtle variations in courtroom speaking styles can influence jurors' reactions and deliberations. Although additional studies would be helpful in strengthening this assertion and in delineating the precise influence of stylistic differences in various courtroom situations, ${ }^{39}$ it is clear from the present studies that issues of presentational style deserve greater attention than they have

39. Particularly important are studies with participants who more closely resemble actual jurors in terms of demographic characteristics and studies in situations where the total context more closely approximates that of the typical trial. 
previously received from both legal scholars and social scientists. ${ }^{40}$

In determining the form which future research and action should take, the obvious threshold question is whether the courts have an obligation to respond to purely linguistic problems. In the powerful/powerless context, it is reasonable to characterize a person's propensity for powerless speech as merely another aspect of his or her self-presentation-much like dress or personal appearance. As courts have never been responsible for compensating for interpersonal or intergroup differences with respect to such features, ${ }^{41}$ successful demands for judicial intervention will have to be based largely on the courts' traditional concern for equity and fundamental fairness. Here the problem of bilingualism in the courts provides a useful analog.

A constitutional right to an interpreter for a non-English speaking defendant has never been recognized. The use of interpreters has been left to the discretion of the trial judge. ${ }^{42}$ Nonetheless, the use of interpreters has become widespread as courts have recognized that the integrity of the judicial process may often require it. ${ }^{43}$ Even Congress has responded to this growning concern by enacting legislation designed to impart some regularity to judicial approaches to problems of bilingual litigants. ${ }^{44}$

Diversity in speech style can plausibly be viewed as a subspecies of the problem of bilingualism: both situations involve functional differences in language use between court and litigant, with the distinction being one of degree rather than kind. However, the extensive docu-

40. See, e.g., H. Giles \& P. PoweSLAND, supra note 11, at 111. See text accompanying notes 1-5 supra.

41. While the courts have held, for example, that individuals may not be excluded from jury pools on the basis of race, see Swain v. Alabama, 380 U.S. 202 (1965), the concept of trial by a jury of one's peers has never been extended to require that jurors be peers of the accused in terms of education or economic background, etc. $C f$. Turner v. Fouche, 396 U.S. 346 (1969) (real property ownership held invalid criterion for school board membership).

42. For a comprehensive review of the current state of the law, see Chang \& Araujo, Inter preters for the Defense: Due Process for the Non-English-Speaking Defendant, 63 CALIF. L. REv. 801 (1975). A constitutional right to an interpreter is recognized only in the federal courts of the Second Circuit. See United States ex rel. Negron v. New York, 434 F.2d 386 (2d Cir. 1970).

43. See, e.g., A Report to the Judicial Council on the Language Needs of NonEnglish Speaking Persons in Relation to the State's Justice System (Judicial Council of Cal. 1976). For an early example of this equitable reasoning in the context of the validity of an admission by a nonnative speaker of English, see People v. Nitti, 312 Ill. 73, 143 N.E. 448 (1924). Two law review articles have been particularly influential in promoting the rights of non-English speakers. Chang \& Araujo, supra note 42; Note, The Right to an Interpreter, 25 RuT. L. REv. 145 (1970).

44. Court Interpreters Act, Pub. L. No. 95-539 (1978).

The educational community has a similar history of tentative response to the bilingual problem. See generally U.S. Comm'N on Civil Rights, A BetTer Chance to Learn: Bilingual Bicultural Education (1975). 
mentation of prejudicial impact that has been developed in the bilingualism context ${ }^{45}$ is lacking in the case of stylistic differences. Data such as the powerful/powerless and narrative/fragmented studies reported here are the first steps in such a process of documentation. With the development of more extensive research to supplement the results obtained here, it is conceivable, as the history of bilingualism in the courts suggests, that a protective judicial response and perhaps, ultimately, legislative action would ensue.

On a more functional level, the findings presented here could be taken into account in a variety of ways. As discussed above, the information being developed could be incorporated into the witness education process. Additionally, lawyers could attempt to impart the importance of linguistic factors to the jury during voir dire, opening statement and closing argument. This might be accomplished by a suggestion by opposing counsel, for example, that the jury take particular note of a hostile witness' use of unassertive language. Conversely, the witness' proponent might urge the jury to ignore the same feature as a purely superficial aspect of the witness' outward appearance. Counsel could also request a jury instruction to the effect that such linguistic factors should be noted or disregarded. However, the jury instruction study outlined above ${ }^{46}$ indicates that such instruction would be ineffective.

Similarly, existing law would appear to make a number of flexible remedial procedures available to trial judges who are sensitive to the significance of presentational style. First, where a witness speaks in a manner similar to the powerless style identified here as a result of age, sex, nationality or the circumstances of the case, judges currently have the authority to permit leading questions on direct examination to prevent unfair prejudice. ${ }^{47}$ There is also ample authority to support the trial judge in intervening directly and questioning the witness himself where he determines, in his sound discretion, that the interests of justice require it. ${ }^{48}$

45. See, e.g., Chang \& Araujo, supra note 42; Note, supra note 43.

46. See text accompanying notes 37-38 supra.

47. See, e.g., United States v. Littlewind, 55I F.2d 244 (8th Cir. 1977) (leading of young rape victims who "responded hesitantly" and were "reticent," $i d$. at 245); Rotolo v. United States, 404 F.2d 316, 317 (5th Cir. 1968) (leading of teenage girl who was "nervous and upset"); People v. Doxie, 34 Cal. App. 2d 511, 93 P.2d 1068 (1939) (leading of five-year-old child witness); Hubbard v. State, 2 Md. App. 364, 234 A.2d 775 (1967) (leading of adult rape victim); State v. Snow, 98 N.H. 1, 4, 93 A.2d 831, 833 (1953) (witness had difficulty with English language).

48. See, e.g., Furtado v. Mantebello Verified School Dist., 206 Cal. App. 2d 72, 23 Cal. Rptr. 476 (1962); State v. Simmons, 98 N.J. Super. 430, 237 A.2d 630, cert. denied, 395 U.S. 924 (1968); cf. Commonwealth v. Butler, $448 \mathrm{~Pa}$. 128, $291 \mathrm{~A} .2 \mathrm{~d} 89,92$ (1972) (trial judge's questioning of alibi 
On a more informal level, the court may simply avail itself of the opportunity to incorporate information such as that reported here into its routine management of the trial. For example, just as judges frequently give witnesses preliminary encouragement to speak loudly and slowly and to tell their story as clearly as possible, they might advise witnesses that it will be in their best interests to speak in a natural, straightforward fashion (that is, not to use hypercorrect or powerless speech) and to use a narrative format whenever possible. Additionally, alerted to the fact that the presence of interruptions may color jurors' perception of the facts, courts may wish to assume an active role in cutting off spontaneous speech episodes in their incipiency. Finally, it may be reasonable in some areas for the courts to draw somewhat more extended inferences from these results. An example of such an extension would be an increased willingness to control the language employed by counsel in closing, premised on the assumption that jurors are likely to be at least as sensitive to the subtleties of the speech of the professional participants in the trial as to that of the lay witnesses. ${ }^{49}$

To the extent that the expedients discussed above could have any effect, they would be satisfactory only as stopgap measures. Since, as the studies indicate, style is of great significance in the reception of testimony, a lasting solution to the problem might well draw on developments in the bilingualism context. Thus, trial court discretion to respond to stylistic variation should be recognized and constrained within appellate guidelines informed by data such as those presented here. It must eventually be recognized that there is a point at which stylistic variance can become so extreme that the communication function of the courtroom is frustrated and the substantive question at issue is wholly obscured. At that point, the only meaningful response might be the use of interpreters-not, in this situation, to mediate between speakers of different languages, but to mediate between speakers of very different versions of the same language. As with bilingualism, uniform legislative guidelines for their selection and use might be the most direct means of ensuring fairness and efficiency.

Ultimately, sensitivity to language variations might be incorporated into the law of evidence itself. The primary concern of legal rules of evidence has always been with threshold questions of admissibility. ${ }^{50}$ Once the elements of admissibility have been met, however, the form in

witness held proper in cases "where an important fact is indefinite or a disputed point needs to be clarified").

49. See note 12 supra.

50. For example, FED. R. Evid. 801-06, a significant portion of the total body of the Rules, deal with the narrow admissibility issue of hearsay. 
which evidence is presented is subject only to very broad constraints. ${ }^{51}$ The express purpose of evidentiary rules is to ensure the reliability of the evidence being admitted. ${ }^{52}$ Arguably, the law cannot be faithful to that purpose if it ignores elements that, in the eyes of the jury, are as significant as factual reliability. Should a witness be held incompetent, for example, if he or she cannot present testimony in a style that will receive an unprejudiced hearing?

The research reported in this Article provides substantial evidence that a witness' testimonial style exerts a strong influence on the jury's perception of the substance of his testimony. To the extent that such influence may distract the jurors from an objective assessment of the facts, the principles of equity, if not constitutional law, require that the courts develop a more active response to the problem. To make a specific contribution to the choice of an appropriate response, experimental research must be expanded greatly beyond the necessarily narrow confines of the initial effort reported here. This Article has sought merely to establish the outline of the problem and to provide a basis for future investigation. However, the trial bar itself must take the lead in guiding further empirical research. The application of social science research tools will be most productive if the questions to be investigated are derived at least in part from practicing lawyers' perceptions of their needs. To reach its full potential, the merger of law and empirical social science must be a merger not just of methodologies but of personnel and ideas as well.

51. Opposing counsel may seek to limit the form in which the adversary elicits testimony by objections to questions that are leading or repetitive or that harass the witness. Judges have wide discretion in ruling on such objections, however, and the prohibitions that underlie them are always subject to exception for reasonable cause. See C. MCCoRMACK, HANDBOOK OF THE LAW OF EVIDENCE $\$ 52$ (1972). Common law rules regarding witness competency, which require that a witness be able to testify intelligently to what the witness has observed, may also provide a basis for challenging testimony on grounds that are in fact largely stylistic. See id. §§ 61-62; cf. FED. R. Evid. 701 (opinion testimony limited to perception of witness).

52. See FED. R. Evid. 102. 


\section{.}

